\title{
ГИПЕРГЕННОЕ РАЗЛОЖЕНИЕ ЧЕРНЫХ МЕТАЛЛОНОСНЫХ СЛАНЦЕВ
}

Отличительной особенностью широко распространенных нижнепалеозойских неметаморфизованных черных сланцев * по сравнению с рядовыми глинами и глинистыми сланцами является пониженное содержание алюминия $(5-7 \%)$ и, наоборот, повышенное содержание углеродистого вещества (у. в.) $(7-15 \%)$ и следующих элементов (\%): K $3-6$; P $0,07-0,5 ; \mathrm{S}_{\text {общ. }} 0,4-6,5 ; \mathrm{N} 0,3-0,6 ;$ Мо $0,01-0,05 ; \mathrm{V} \quad 0,065-0,1$; $\mathrm{U} 0,009-0,03\left[{ }^{1-4}\right]$. В коренном залегании они обычно водонепроницаемы, и поэтому подвергаются воздействию агентов выветривания лишь в обнажениях около дневной поверхности, о чем свидетельствуют нижеприведенные данные. Содержание сульфатной серы, являющейся продуктом окисления пирита и марказита на естественных выходах сланцев, достигает местами 2,6 против $0,5-1,8 \%$ в невыветрелых сланцах. Изменение содержания сульфатной серы в сланцах с глубиной от поверхности обнажения следующее: 30 сми - 2,60\%, $60-1,77,90-1,41,120-1,19$, $150-0,47,180-0,50$. Окисление пиритной серы приводит к образованию $\mathrm{H}_{2} \mathrm{SO}_{4}$ и $\mathrm{Fe}_{2}\left(\mathrm{SO}_{4}\right)_{3}$, под воздействием которых происходит растворение ряда металлов (табл. 1).

Опробование невыветрелых сланцев при их выемке и тех же сланцев, пролежавших в отвале в течение трех лет и превратившихся в дресву, показало, что за это время атмосферными осадками было выщелочено до $45 \%$ находящегося в них урана; в лабораторных условиях из них водой дополнительно было извлечено $20 \%$ U. Итак, за три года под воздействием агентов выветривания переводится в водорастворимое состояние до $65 \%$ U.

Таблица 1

\section{Содержание отдельных элементов в невыветрелых, выветрелых в коренном залегании и извлеченных из недр, пролежавших в отвалах два года образцах (S, Fe в \%; Mo, V, U в 10-3 \%)}

\begin{tabular}{l|c|c|c|c|c|c}
\hline \multicolumn{1}{c|}{ Образцы } & $\mathrm{S}\left(\mathrm{S}^{2-}\right)$ & $\mathrm{S}\left(\mathrm{SO}_{4}^{2-}\right)$ & $\mathrm{Fe}$ & $\mathrm{Mo}$ & $\mathrm{V}$ & $\mathrm{U}$ \\
\hline & $5,05-5,65$ & $1,76-1,84$ & $6,03-6,20$ & $40-50$ & $84-112$ & $29-36$ \\
Невыветрелые & $2,65-3,40$ & $2,02-2,60$ & $5,32-5,46$ & $42-50$ & $73-123$ & $30-32$ \\
Выветрелые & $2,73-2,98$ & $4,75-5,90$ & $5,08-5,19$ & $40-40$ & $78-84$ & $17-25$ \\
Добытые (лежалые)
\end{tabular}

* В литературе неметаморфизованные разности этих пород иногда называются квасцовыми, граптолитовыми нли глинистыми сланцами, а также просто аргиллитами или алевролит-аргиллитовыми сланцами.

1 ENSV TA Toimetised. K 31980 
Гипергенное разложение вещества сланцев начинается с окисления пирита и марказита под воздействием тионовых бактерий. Наличие их установлено микробиологическим опробованием выветрелых сланцев, a их роль в гипергенном разложении вещества этих пород - лабораторными экспериментами, которые показали следующее. В стерильных условиях из невыветрелых сланцев водой удается извлечь около $14 \% \mathrm{U}$ от общего его содержания, тогда как при внесении культуры Thiobacillus ferrooxidans за три месяца водой выщелачивается (\%): $70 \mathrm{U}$. 30 Мо и $20 \mathrm{~V}$, а за девять месяцев $-82 \mathrm{U}$ и $60 \mathrm{Mo.}$

Окисление сульфидов является экзотермическим процессом, вызывающим разогрев разлагающегося вещества, а затем в результате этого разогрева происходит самовозгорание у. в. Горение сланцев в отвалах длится месяцами, иногда более года, несколько замирая, но не прекращаясь в зимних условиях. Пожары возникают в одних случаях через несколько месяцев после образования отвала, в других через 10-12 лет. Измерение температуры горящего отвала показывает, что на поверхности над очагами горения она достигает $70-300^{\circ} \mathrm{C}$, но, судя по окраске золы сланца, температура на глубине отвала может превышать $1000^{\circ}$. Воспламенение подобных сланцев происходит при $246^{\circ}\left[{ }^{5}\right]$.

Изучение района одного из небольших рудников, где сланцы извлекаются из недр и сбрасываются в отвал, показало, что в результате самовозгорания сланцев происходит заражение как атмосферы, так и гидросферы.

Количество сернистого ангидрида, выделяющегося в атмосферу, оценено еще не очень точно, хотя ориентировочные данные можно привести. На этом руднике ежегодно вскрывается карьером около 35 га, что приводит к сбрасыванию в отвал более 2 млн. т сланцев, содержащих 77 тыс. $т$ пиритной и 18 тыс. $т$ органической серы. Самовозгорание происходит на $30-70 \%$ отработанной площади, при этом $\approx 60 \%$ пиритной серы и практически вся органическая сера превращаются в $\mathrm{SO}_{2}$, который выделяется в атмосферу и частично попадает в сточные воды карьера и грунтовые воды окружающей карьер местности. Вместе с заводскими выбросами других вредных компонентов он заражает атмосферу на площади порядка $100 \kappa \mu^{2}$.

Результаты изучения поверхностных и просочившихся через отвалы вод на этом руднике и в его окрестностях (табл. 2) свидетельствуют прежде всего о том, что состав воды на отвалах рудника резко отличается от вод озера и ручья как в отношении общей минерализации и кислотности, так и по содержанию ряда металлов. Отмечаются также значительные отличия состава в пробах вод, отобранных в разных точках по площади рудничных отвалов. При повторном опробовании вод через 20 сут существенные отличия не установлены, однако есть основания ожидать заметные сезонные колебания содержания металлов в их составе в зависимости от обильности атмосферных осадков, интенсивности развития микрофлоры и других факторов, поскольку при опробовании одних и тех же точек в июле и октябре содержания U в воде отличались в $2-3$ раза.

Пути миграции высокоминерализованных атмосферных осадков через отвалы сланцев еще не изучены. Можно опасаться, что эти воды могут попадать в открытые водоемы и подземные бассейны, используемые для различных целей. Кроме того, не исключено, что лри артезианских бассейнах возможно постепенное повышение концентрации ряда компонентов по мере развития карьерной отработки месторождения.

Режим горения сланцев и его роль в возникновении высоких концентраций металлов в разных водах рудника были изучены лаборатор- 


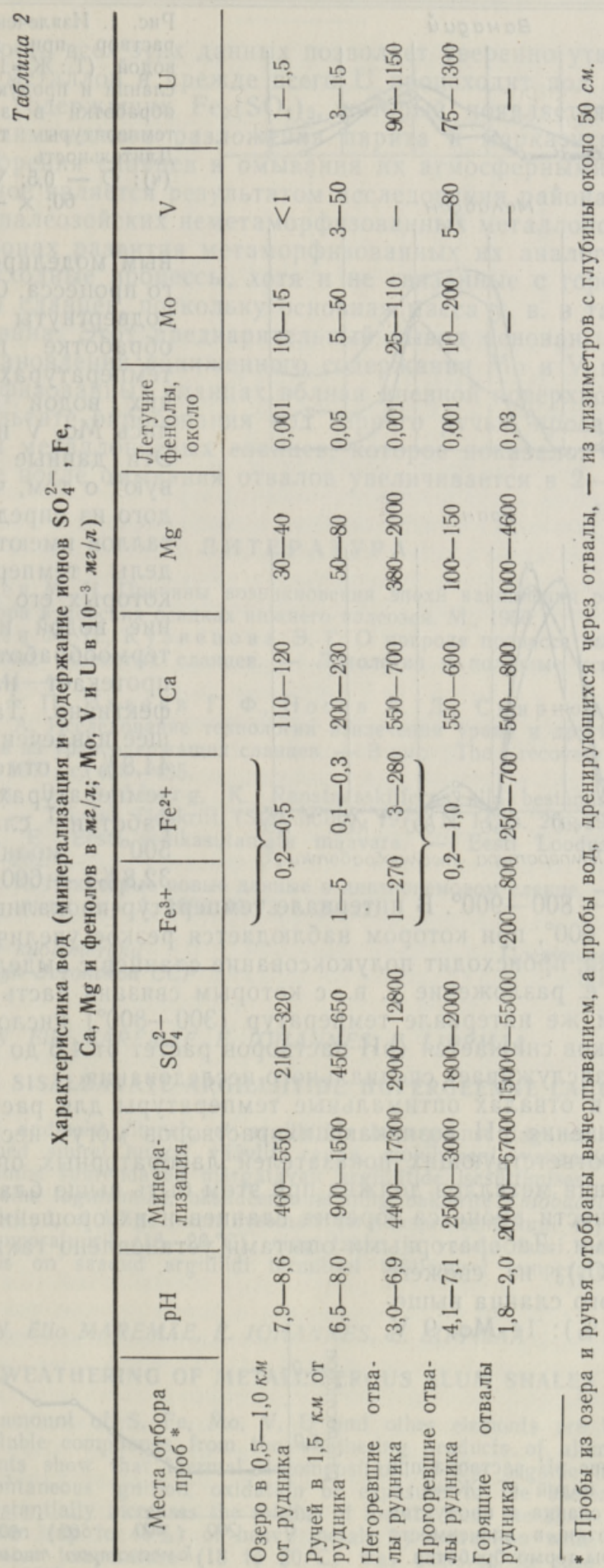



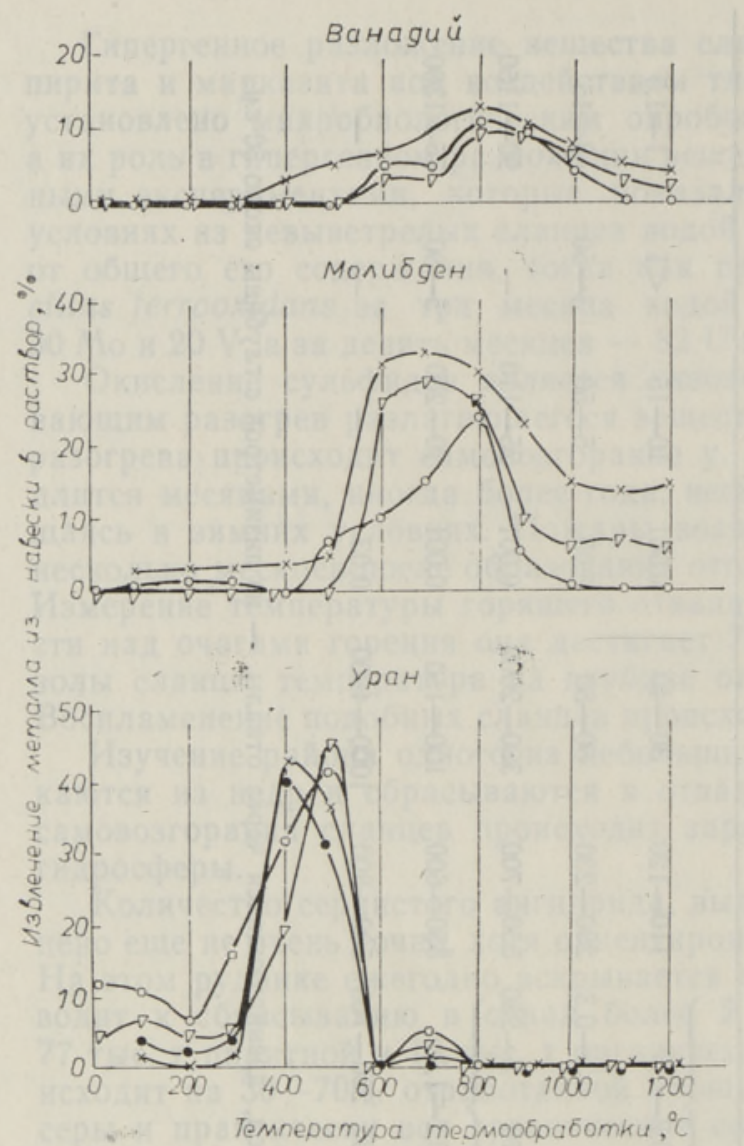

Рис. 1. Извлечение металлов в раствор при выщелачивании водой $\left(\mathrm{T}: Ж=1: 5,18-20^{\circ} \mathrm{C}\right)$ сланца и продуктов его термообработки в зависимости от температуры термообработки. Длительность выщелачивания (ч): $\bigcirc-0,5 ; \nabla-7,5 ; \square-$ $60 ; \times-100$.

ным моделированием этого процесса. Сланцы были подвергнуты термнческой обработке при разных температурах, а затем из них водой выщелачивались Мо, V и U (рис. 1). Әти данные свидетельствуют о том, что для каждого из определяемых металлов имеются свои пределы температуры, при которых его выщелачивание водой из продуктов термообработки сланца протекает наиболее эффективно. Так, наибольшее извлечение урана (до $44,8 \%$ ) отмечалось при температурах термообработки сланца 400-$500^{\circ}$, молибдена (до $32,8 \%)-600-800^{\circ}$, вана-

дия $(12,5 \%)-800-900^{\circ}$. В интервале температур прокаливания сланца между 300 и $600^{\circ}$, при котором наблюдается резкое увеличение растворимости урана, происходит полукоксование сланцев с выделением масел и смол [6], т. е. разложение у. в., с которым связана часть урана. Примерно в этом же интервале температур $\left(300-800^{\circ}\right)$ кислотность полученных щелоков снижается (рН растворов растет от 4,6 до 5,9) (рис. 2 ). Это явление заслуживает специального исследования.

Конечно, в отвалах оптимальные температуры для растворения металлов и значения рН возникающих растворов могут несколько отличаться от соответствующих показателей лабораторных опытов, а степень извлечения металлов должна при этом быть выше благодаря большей длительности процесса горения сланцев и их орошению атмосферными осадками. Лабораторными опытами установлено также, что раствором $\mathrm{Fe}_{2}\left(\mathrm{SO}_{4}\right)_{3}$ из свежего необожженного сланца выщелачивается $(\%): 14 \mathrm{Mo}, 9 \mathrm{~V}$, 39 U.

Рис. 2. Изменение $\mathrm{pH}$ раствора при выщелачивании водой ( $\mathrm{T}: Ж=1: 5$, $18-20^{\circ} \mathrm{C}, 7$ 4) сланща и продуктов его термообработки в зависимости от температуры термообработки.

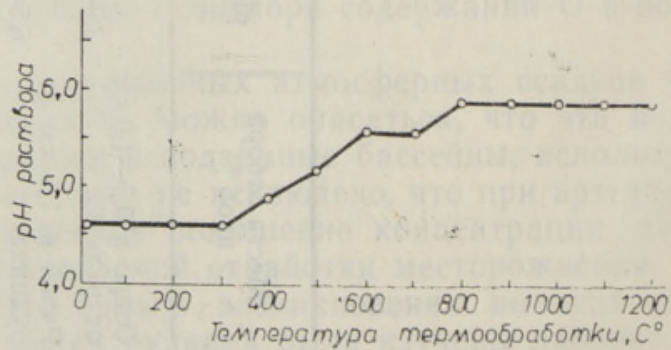


Совокупность всех этих данных позволяет уверенно утверждать, что растворение металлов и прежде всего U происходит под воздействием кислых вод, содержащих $\mathrm{Fe}_{2}\left(\mathrm{SO}_{4}\right)_{3}$, который появляется сперва как продукт биохимического разложения пирита и марказита, а затем в результате горения сланцев и омывания их атмосферными осадками.

Изложенное является результатом исследования района распространения нижнепалеозойских неметаморфизованных металлоносных черных сланцев. В зонах развития метаморфизованных их аналогов, вероятно, происходят сходные процессы, хотя и не связанные с горением (самовозгоранием) сланцев, поскольку основная масса у. в. в таких сланцах графитизирована. Этот предварительный вывод основан, с одной стороны, на установлении пониженного содержания Мо и V в трещиноватых метаморфизованных сланцах вблизи дневной поверхности и, с другой, на результате опробования вод горного ручья, просачивающегося через отвалы металлоносных сланцев, которое показало, что содержание $\mathrm{U}$ в воде после омывания отвалов увеличивается в $2-3$ раза.

\section{Л ИТЕ РАТ У Р А}

1. Альтга узен М. Н. Причины возникновения эпохи накопления редких металлов и фосфора в морских осадках нижнего палеозоя. М., 1956.

2. Альтгаузен М. Н., К узнедов а Э. Г. О природе процесса выветривания пиритоносных глинистых сланцев. - Литология и полезные ископаемые, 1973, № 2 , c. $41-49$.

3. Зефиров А. П., Иванов Г. Ф., Носов В. Д., Смирнов И. П., Гае в ой П. А. Исследование технологии извлечения урана и других ценных компонентов из урансодержащих сланцев. - В кн.: The recovery of uranium Vienna, 1971 , c. $425-435$.

4. Oscarsson, B., S jöberg, K. Ranstadsskifferns alla bestandsdelar skall tas tillvara. - Teknisk Tidskrift (Stockholm), 1977, N 14, s. 26-29.

5. Kivimägi, E. Eesti senikasutamata maavara. - Eesti Loodus, 1974, nr. 4, lk. $199-202$.

6. С и й рде А. К. Некоторые новые данные о диктионемовом сланце. - Тр. Таллинск. политех. ин-та. Сер. А, 1956 , № 73 , с. $3-22$.

Ннститут кибернетики

Академии наук Эстонской ССР
Поступила в редакцию 5/IV 1979

\section{ALTHAUSEN, Ello MAREMAE, E. JOHANNES, E. LIPPMAA}

\section{METALLE SISALDAVATE ARGILLIITIDE HUPERGEENNE LAGUNEMINE}

Artiklis esitatud andmeist ilmneb, et argilliitide hüpergeense lagunemise produktidest leostavad sademed suurel hulgal väävlit, rauda, molübdeeni, vanaadiumi, uraani jt. elemente. Leostamist suurendavad märgatavalt argilliitide isesüttimisest tingitud orgaanilise aine termiline lagunemine, oksüdeerimine ning bakterite Thiobacillus ferrooxidans elutegevus. On leitud, et kõige intensiivsemalt (eraldusprotsent kuni 45) leostuvad raskemetallid toatemperatuuril $\left(18-20^{\circ} \mathrm{C}\right)$ ning tahke ja vedela faasi suhte $1: 5$ korral produktidest, mis on saadud argilliidi termilisel töötlemisel temperatuuril $400-800^{\circ}$.

\section{ALTHAUSEN, Ello MAREMAE, E. JOHANNES, E. LIPPMAA}

\section{WEATHERING OF METALLIFEROUS ALUM SHALES}

A considerable amount of $\mathrm{S}, \mathrm{Fe}, \mathrm{Mo}, \mathrm{V}, \mathrm{U}$ and other elements are leached out by rainwater as soluble compounds from the weathering products of alum shales. Laboratory experiments show that thermal decomposition of the organic matter of alum shales after spontaneous ignition, oxidation or exposure to the bacteria Thiobacillus ferrooxidans substantially increases the release of metals from the shale. The most pronounced separation (up to $45 \%$ ) of heavy metals by extraction with water (at $1: 5$ $\mathrm{s} / \mathrm{w}$ ratio) at room temperature $\left(18\right.$ to $\left.20^{\circ} \mathrm{C}\right)$ was achieved in case of alum shale roasted at 400 to $800^{\circ}$. 